\title{
Acil Servis Çalışanlarında Şiddete Maruz Kalma Durumunun İncelenmesi
}

\author{
Sibel Coşkun ${ }^{1}$, Seçkin Karahan² ${ }^{2}$
}

'Dokuz Eylül Üniversitesi, Hemşirelik Fakültesi, İzmir, Türkiye 2Sağlık Bakanlığı, Köyceğiz Devlet Hastanesi, Muğla, Türkiye

Sibel Coşkun, Dr. Öğr. Üyesi Seçkin Karahan, Hemşire

Iletişim:

Dr. Öğr. Üyesi Sibel Coşkun Dokuz Eylül Üniversitesi, Hemşirelik Fakültesi, İzmir, Türkiye

Tel: +902324126993

E-Posta: cosibel@gmail.com

Gönderilme Tarihi : 05 Ekim 2017

Revizyon Tarihi : 120 cak 2018

Kabul Tarihi : : 120cak 2018

\section{ÖZET}

Amaç: Şiddet günümüzün önemli sorunlarındandır ve hastanelerin acil servis üniteleri şiddete maruz kalma riskinin daha fazla olduğu ortamlardandır. Muğla ilinde gerçekleştirilen bu tanımlayıcı çalışma, kamu hastaneleri acil servislerinde görevli sağık çalışanlarının şiddete maruz kalma durumlarının incelenmesi amacıyla yapılmıştır.

Gereç ve Yöntem: Çalışma; Muğla il ve ilçe kamu hastaneleri acil servislerinde çalışan toplam 280 sağlık personeli evreni, çalışmaya katılmayı kabul eden 198 sağlık personeli örneklemi oluşturmuştur. Verilerin toplanmasında, araştırmacılarca literatür doğrultusunda oluşturulmuş 40 soruluk anket formu kullanılmıştır. Veriler bilgisayar ortamında sayı yüzde hesaplamaları ile ki-kare testi kullanılarak değerlendirilmiştir.

Bulgular: Araştırmaya katılanların \%69,7'si kadın, \%76,8'i hemşire ve \%57,6'sı 0-5 yıldır acil serviste çalışmaktadır. Çalışanların \%90,4'ü ü sözel şiddete, \%23,2'si fiziksel şiddete maruz kalmıştı. Sözel şiddet olgularının çoğu hasta yakını tarafından gerçekleştirilmiştir. Şiddete maruziyet sonrası çalışanlarda en çok öfke ve işten soğuma duyguları saptanmıştır. Fiziksel şiddetin bildirim/ raporlama oranı \%64 olarak belirlenmiş, şiddete maruz kalanlarda psikolojik destek alma oranları ise çok düş̧ük bulunmuştur. 1-5 yıl süredir acil serviste çalışanlarda şiddete maruz kalma oranları daha yüksek olup şiddete maruz kalanların çoğunda çalıştığı birimi değiştirme isteği belirlenmiştir.

Sonuç: Sonuç olarak; çalışanların güvenliğini sağlamaya yönelik tedbirlerin arttııılması, yasal yaptırımların caydııııılı̆ıııın sağlanması, ülkemizde daha etkin ve planlı şiddet önleme programlarının uygulanması gerektiği düşünülmektedir.

Anahtar sözcükler: Şiddet, işyerinde şiddet, acil servis, sağlık çalışanları, iş güvenliği

\section{AN ANALYSIS OF EMERGENCY DEPARTMENT WORKERS' EXPOSURE TO VIOLENCE}

\section{ABSTRACT}

Purpose: Workplace violence is a key current issue, and it is clear that emergency departments within hospitals are environments with an elevated risk of exposure to violence. This descriptive study was conducted in Muğla Province to examine exposure to violence amongst health professionals working in emergency departments.

Methods: The population of the study included 280 health professionals working within the emergency departments of public hospitals located in the province of Muğla. The sample included 198 health professionals who had agreed to participate in the study. The study data were collected using a questionnaire involving 40 responses which was specially created by the researchers based on relevant previous literature. Data analysis was undertaken by computer using the chi-squared test and by calculating numbers and percentages.

Results: 0 f the participants, $69.7 \%$ were female, $76.8 \%$ were nurses, and $57.6 \%$ had been working in the emergency department for between one and five years. $90.4 \%$ had been exposed to verbal abuse, while $23.2 \%$ had been exposed to actual physical violence. A majority of the manifestations of verbal abuse came from patients' relatives. After being exposed to violence, it was determined that workers felt anger, and they felt distant from their work. The rate of notification/reporting of physical violence was $64 \%$, and the rate of receiving psychological support in those that were exposed to violence, was extremely low. It was also found that a majority of healthcare workers thus exposed wished to change the department where they were working.

Conclusion: We suggest that the number of precautions for ensuring workers' safety should be increased, legal sanctions should be made more effective as a deterrent, and programmes for preventing violence should be more effective and well-planned in our country.

Keywords: Workplace violence, emergency department, healthcare worker, workplace safety 
eçmişi insanlık tarihi kadar eski olan şiddet; bireyselliğe ve insan haklarına bir saldırı olup, toplumun pek çok kesimini ve pek çok mesleği etkileyen günümüzün önemli bir sosyal sorunudur $(1,2)$. Şiddet türleri ise; fiziksel, sözel (hakaret vb), psikolojik (tehdit vb) ve cinsel şiddet olarak sınıflanmaktadır. Literatürde hastanelerin yüksek riskli çalışma ortamları olduğu, sağlık sektöründe şiddet oranlarının giderek arttığı belirtilmekte $(3,4,5,6)$, Amerika'da 3. sırada sağlık sektöründeki yaralanmaların yer aldığı raporlanmaktadır (7). Acil servisler ise şiddetin en çok gerçekleştiği üniteler olup, yapılan çalışmalarda sözel şiddet en yüksek oranlara sahiptir $(3,5)$.

Türkiye'de sağlık çalışanlarının, çalışma yaşamı boyunca işyerinde herhangi bir şiddet türü ile karşılaşma oranı \%74 olup (4), sözlü şiddet $\% 80,3$ ile $\% 100$, fiziksel şiddet $\% 16$ ile $\% 49,4$ ve cinsel taciz \%3 ile \%37,1 arası değiştiği belirtilmektedir (8). Bu oranlar İspanya'da yapılan sözlü şiddet için $\% 38$ ile $\% 90$, fiziksel şiddet ise $\% 11$ ile $\% 71$ arası değişmekte olup (6), Yunanistan'da sağlık çalışanlarının \%83,4'ünün (9) Amerika'da \%35-80 arasında değişen oranlarda şiddete maruz kaldığı aktarılmaktadır (3). Türkiye'de 2012-2015 yılları arasında Sağlık Bakanlığı́na bildirilmiş 31.767 şiddet vakası yaşandığı, şiddete maruz kalanların 18.000'i hekim, 13.767 'si ise hemşire ağılıklı sağlık çalışanlarından oluştuğu, saldırıların 14.250'sinin fiziksel, 17.517'sinin ise sözlü şiddet olduğu belirtilmektedir (10). Şiddet ile ilgili değişkenler ise oldukça çeşitlidir. Bazı çalışmalarda hemşirelerin hekimlerden daha fazla şiddete maruz kaldığı, yaşın bir risk faktörü olduğu görülmekte $(1,11,12)$, şiddetin psikiyatrik üniteler, acil servisler, poliklinikler ile bekleme salonları ve geriatrik birimlerde daha sık görüldüğü belirtilmektedir $(11,12,13)$. Özellikle acil servisler; akut, hayati risk oluşturan, acı çeken ve riskli vakaların başvurduğu, stresli hatta kaotik ortamlardır. Ve ilave olarak iletişim aksaklıklarının yaşanması da şiddet davranışını tetikleyebilmektedir $(3,6,7,8,14)$.

Şiddetin çalışanlara ve sunulan hizmete pek çok olumsuz etkileri söz konusudur. Bunlar; fiziksel yaralanma, olumsuz duygular, depresyon, anksiyete, alkol \& madde kullanımı, uyku bozuklukları gibi ruhsal sorunlar, tükenmişlik, iş doyumunda azalma ve hizmet kalitesinde düşme gibi çok çeşitlidir $(5,7,13,15,16,17)$. Ülkemizde de iş güvenliğine yönelik önlemler arttırılmış, sağlık kurumlarında yaşanan şiddete olaylarına müdahalede ve bildirimde beyaz kod uygulaması yaygınlaştııılmış olsa da sağlık çalışanlarına yönelik şiddetin önlenmesi için daha etkin programlar ve girişimlere gereksinim duyulmaktadır. Bu çalışma amaç: Muğla ili kamu hastanelerinin acil servislerinde çalışan sağlık personelinin şiddete maruz kalma durumları ile çalışma ortamına ilişkin özelliklerin incelenmesidir.

\section{Gereç ve yöntem}

Tanımlayıcı nitelikteki bu araştırma; Aralık 2016 - Ocak 2017 tarihlerinde, Muğla il merkezi ve ilçelerinde bulunan 10 kamu hastanesinde yürütülmüştür. Hastanelerin acil servislerinde çalışan toplam 280 sağlık personeli (hemşire, hekim, acil tıp teknisyeni) evreni, çalışmaya katılmayı kabul eden 198 sağlık personeli örneklemi oluşturmuştur.

Verilerin toplanmasında, araştırmacılarca literatür doğrultusunda oluşturulan 40 soruluk anket formu kullanılmıştır. Ankette sağlık çalışanlarının sosyodemografik ve mesleki özellikleri, çalışma koşulları, iş ortamında karşılaştıkları şiddet olayları ile ilgili sorular bulunmaktadır. Çalışmada, acil servis birimlerine gidilerek sağlık çalışanlarına gerekli sözel açıklamalar yapılmıştır. Çalışmaya katılmayı kabul eden ve müsait olan sağlık çalışanları anketleri doldurup araştırmacıya teslim etmişler, meşgul olanlar ve nöbet ekipleri için birim sorumlularına anketler teslim edilmiş ve iki hafta sonra geri toplanmıştır. Çalışmada anketlerden elde edilen veriler kodlanarak bilgisayar ortamına aktarılmış, veriler SPSS istatistik programı ile, sayı, yüzde hesaplamaları ve ki-kare testi kullanılarak, 0,05 önemlilik düzeyine göre değerlendirilmiştir. Çalışmada Muğla Sıtkı Koçman Üniversitesi Etik Kurulu'ndan onam ve gerekli kurumsal izinler alınmış olup katılımcıların kişisel bilgilerinin gizliliğine dikkat edilmiştir.

\section{Bulgular}

Araştırmaya katılan acil servis çalışanlarının \%69,7'si kadın \%30,3'ü erkektir, \%32,8'i 35-39 yaş grubunda, \%24,2'si 40 yaş üzerdir ve \%70,2'si evlidir. Katılımcıların \%76,8'i hemşire \%18,2'si hekim olup \%35,4'ü lisans, \%23,7'si lisansüstü eğitimine sahiptir. Örneklemin mesleki ve çalışma ortamına ilişkin özellikleri incelendiğinde; \%36,9'u 15 yıl üzeri, \%30,8'i 0-5 yıldır meslekte ve \%57,6'sı 0-5 yıldır acil serviste çalışmaktadır. \%68,2'si kendi tercihi ile acil serviste çaıışmaya başladığını belirtmiş olsa da katılımcıların sadece $\% 10,6$ 'sı çalışma koşullarından memnundur ve $\% 63,6$ 'sında ise acil servisten ayrılma isteği bulunmaktadır.

Çalışanların \%90,4'ü $(n=179)$ bir ya da daha fazla kez sözel şiddete maruz kalmıştır. Şiddet davranışı olarak $\% 32,9$ oranında hakaret, ve sözel şiddet kaynağı \%50.8 oranında hasta yakını olarak belirlenmiştir. Sözel şiddet sonrası çalışanlarda duygusal tepki olarak \%30 oranında öfke, \%25,8 oranında işten soğuma/isteksizlik belirtilmiştir (Tablo 1). Sözel şiddete maruz kalanların $(n=179)$ $\% 43,5^{\prime} i$ en az bir şiddet olayı için beyaz kod bildiriminde bulunmuş olup, bildirimlerin yarısında yasal işlem uygulandığı/devam ettiği, yarısında ise tatmin edici bir sonuç 
Tablo 1. Acil servis çalışanlarında sözel saldıııa uğrama durumu ve özellikleri

\begin{tabular}{|c|c|c|}
\hline & $n$ & $\%$ \\
\hline \multicolumn{3}{|c|}{ Sözel Şiddete Uğrama } \\
\hline Hayır & 19 & 9,6 \\
\hline $1-5 \mathrm{kez}$ & 101 & 51,0 \\
\hline 6-10 kez & 32 & 16,1 \\
\hline 10 dan fazla & 46 & 23,3 \\
\hline Toplam & 198 & 100 \\
\hline \multicolumn{3}{|c|}{ Sözel Saldırı Türü } \\
\hline Küfür & 102 & 22,2 \\
\hline Tehdit & 97 & 21,1 \\
\hline Hakaret & 151 & 32,9 \\
\hline Küçük düşürme & 77 & 16,8 \\
\hline Sözlü taciz & 18 & 3,9 \\
\hline Diğer & 14 & 3,1 \\
\hline Toplam & $459^{*}$ & 100 \\
\hline \multicolumn{3}{|c|}{ Sözel Saldırı Kaynağı } \\
\hline Hasta & 135 & 41,0 \\
\hline Hasta yakını & 167 & 50,8 \\
\hline Sağlık çalışanı & 20 & 6,1 \\
\hline Diğer & 7 & 2,1 \\
\hline Toplam & $329 *$ & 100 \\
\hline \multicolumn{3}{|c|}{ Oluşan Duygusal Tepkiler } \\
\hline Önemsememe & 40 & 10,0 \\
\hline Korku & 26 & 6,5 \\
\hline Tiksinme & 59 & 14,7 \\
\hline Öfke & 120 & 30,0 \\
\hline Aşağılanmışlık & 52 & 13,0 \\
\hline İşten soğuma & 103 & 25,8 \\
\hline Toplam & $400^{*}$ & 100 \\
\hline
\end{tabular}

alınamadığı belirlenmiştir. Ayrıca sözel şiddete maruz kalanların \%15,6'sının ( $n=28)$ psikolojik desteğe ihtiyaç duyduğu ve sadece 7 kişinin psikolojik destek için başvurduğu tespit edilmiştir.

Örneklemde fiziksel şiddete maruz kalma oranı \%23,2 $(n=46)$ olarak tespit edilmiş olup şiddet davranışının \%33'ü itme, \%17,3'ü eşya fırlatma şeklinde gerçekleşmiştir. Fiziksel şiddete maruz kalan sağlık çalışanlarının $\% 53,4$ 'ünün herhangi bir yara almadığı ve olguların \%45,5 oranında hasta, \%41,5 oranında hasta yakını kaynaklı olduğu görülmektedir (Tablo 2). Fiziksel şiddete maruz
Tablo 2. Acil servis çalışanlarında fiziksel saldırıya uğrama durumu ve özellikleri $(n=198)$

\begin{tabular}{lcc} 
& $\boldsymbol{n}$ & $\%$ \\
\hline Fiziksel Şiddet Uğrama & 152 & 76,8 \\
Hayır & 42 & 21,2 \\
$1-5 \mathrm{kez}$ & 2 & 1,0 \\
$6-10 \mathrm{kez}$ & 2 & 1,0 \\
10 dan fazla & 198 & 100 \\
Toplam & &
\end{tabular}

\section{Fiziksel Saldırı Çeşitleri}

Yumruk

Tokat

5,9

İtme

33,0

Isırma

4,9

Tekme

13,6

Kesi

3,9

Cinsel taciz

4,9

Eşya atma

17,3

Diğer

4,9

Toplam

100

\section{Fiziksel Saldırı Kaynağı}

Hasta

45,5

Hasta yakını

41,5

Sağlık çalışanı

11,7

Diğer

1,3

Toplam

100

Oluşan Fiziksel Etki

Kurtulma

53,4

Hafif yara

18,3

Çürük ezilme

18,3

Ağır yara

3,3

Diğer

6,7

Toplam

100

Oluşan Duygusal Tepkiler

Önemsememe 54,0

Korku $12 \quad 9,5$

Tiksinme

16,6

Öfke

29,4

Aşağılanmıısılık

15,1

İşten soğuma/(İsteksizlik)

23,8

Diğer

1,6

Toplam

100 
kalanların \%37'sinin $(n=17)$ psikolojik destek gereksinimi duyduğu ve sadece 3 kişinin psikolojik destek aldığı ve toplamda 4 kişinin izin/rapor kullandığı belirlenmiştir. Ayrıca \%64,5'inin ( $n=30$ ) fiziksel şiddet ile ilgili beyaz kod bildiriminde bulunduğu, bunların \%51,5'inde yasal işlem uygulandığı, \%45,6'sında tatmin edici bir yanıt alınamadığı ya da uzlaştırma ile sonuçlandığı tespit edilmiştir.

Acil servis çalışanlarının sadece \%5,6'sı çalıştıkları birimdeki güvenlik tedbirlerini yeterli bulmakta olup, daha çok güvenlik personeli bulundurma ve kamera kaydı gibi tedbirlerin kullanıldığı belirlenmiştir. Oluşan şiddet olaylarının en fazla triyaj ve hasta kabul $(\% 41,2)$ birimi ile muayene ya da müdahale odasında $(\% 37,9)$ gerçekleştiği tespit edilmiştir (Tablo 3). Ayrıca; çalışanların \%88, $9^{\prime} u$ acil servis ortamını diğer bölümlere kıyasla daha riskli bulmaktadır. $\% 96$ 'sı iş ortamındaki şiddet riskinin iş stresini arttırdığını ve \%99'u iş riski nedeniyle yapılan döner sermaye ek ödemesini yeterli bulmadığını belirtmiştir. Yaş, cinsiyet, meslek, eğitim durumu vb gibi diğer değişkenlere göre şiddete maruz kalma durumu karşılaştırıldığında herhangi bir anlamlı bir farklılık saptanmamıştır. Sağlık çalışanlarının

Tablo 3. Çalışanlarda şiddete maruz kalınan yer ve mevcut güvenlik tedbiri özelliklerinin dağılımı $(\mathrm{n}=198)$

\begin{tabular}{lcc} 
& $\boldsymbol{n}$ & $\%$ \\
\hline Acil Servis Güvenlik Yeterliliği & 11 & 5,6 \\
Evet & 85 & 42,9 \\
Hayır & 102 & 51,5 \\
Kısmen & $\mathbf{1 9 8}$ & $\mathbf{1 0 0}$ \\
Toplam & & \\
\hline Mevcut Güvenlik Önlemleri & 198 & 41,4 \\
Güvenlik personeli & 183 & 38,3 \\
Kamera & 33 & 6,9 \\
Alarm/Zil & 58 & 12,1 \\
Acil çıkıŞ & 6 & 1,3 \\
İzolasyon odası & $\mathbf{4 7 8 *}$ & $\mathbf{1 0 0}$ \\
Toplam & & \\
\hline Şiddete Maruz Kalınan Yer & 164 & $\mathbf{1 0 0}$ \\
Triyaj/Hasta kabul & 150 & 15,4 \\
Muayene vb odası & 7 & 37,9 \\
Telefon & 61 & \\
Bekleme salonu & 14 & \\
Koridor/Bahçe & & \\
Toplam & & \\
\hline *n katlanmıştır. & & \\
& & \\
\hline
\end{tabular}

fiziksel şiddete maruz kalma durumuna göre acil serviste çalışma yılı ve çalıştığı birimi değiştirme düşüncesi karşılaştırıldığında 1-5 yıl süredir acil serviste çalışmakta olanların daha fazla fiziksel şiddete maruz kaldığı $\left(X^{2}=10,40\right.$; $p=0,006)$ ve fiziksel şiddete maruz kalanlarda acil servisten ayrılma düşüncesinin daha fazla $\left(X^{2}=9,51 ; p=0,009\right)$ ve bu farklılıkların istatistiksel olarak anlamlı olduğu saptanmıştır (Tablo 4). Sağlık çalışanlarının sözel saldırıya uğrama durumu ile çalışma koşullarından memnuniyeti karşılaştırıldığında ise, sözel şiddete maruz kalanlarda çalışma koşullarından memnun olmayanların oranı daha fazladır ve istatistiksel olarak anlamlı farklılık $\left(X^{2}=6,73, p=0,035\right)$ saptanmıştır (Tablo 5).

Tablo 4. Çalışanlarda fiziksel şiddete maruz kalma durumuna göre çalışma yllı ve acil servisten ayrılma düşüncesinin karşılaştırıması

Fiziksel Şiddete Uğrama

\begin{tabular}{lccc}
\hline & $\begin{array}{c}\text { Evet } \\
\%(\boldsymbol{n})\end{array}$ & $\begin{array}{c}\text { Hayır } \\
\%(\boldsymbol{n})\end{array}$ & $\begin{array}{c}\text { Toplam } \\
\%(\boldsymbol{n})\end{array}$ \\
\hline Acil Serviste Çalışma Yılı & & & \\
1-5 yıl & $9,5(19)$ & $48,0(95)$ & $57,5(114)$ \\
6-10 yıl & $6,6(13)$ & $19,7(39)$ & $26,3(52)$ \\
11 yıl ve & $7,1(14)$ & $9,1(18)$ & $16,2(32)$ \\
Toplam & $23,2(46)$ & $76,8(152)$ & $100(198)$ \\
$X^{2}=10,40 ; p=0,006$ & & &
\end{tabular}

Acil Servisten Ayrılma Düşüncesi

$\begin{array}{lccc}\text { Evet sık } & 10,0(20) & 17,2(34) & 27,2(54) \\ \text { Hayır } & 5,1(10) & 31,8(63) & 36,9(73) \\ \text { Bazen } & 8,1(16) & 27,8(55) & 35,9(71) \\ \text { Toplam } & 23,2(46) & 76,8(152) & 100(198) \\ \mathbf{X}^{2}=9,51 ; \mathbf{p = 0 , 0 0 9} & & & \end{array}$

Tablo 5. Çalışanlarının çalışma koşullarından memnuniyeti ile sözel şiddete uğrama durumunun karşllaştırıması.

\begin{tabular}{|c|c|c|c|}
\hline \multirow[t]{2}{*}{$\begin{array}{l}\text { Çalışma Koşullarından } \\
\text { Memnuniyet }\end{array}$} & \multicolumn{2}{|c|}{ Sözel Şiddete Uğrama } & \multirow[t]{2}{*}{ Toplam \% (n) } \\
\hline & $\begin{array}{l}\text { Hayır } \\
\%(n)\end{array}$ & $\begin{array}{l}\text { Evet } \\
\%(n)\end{array}$ & \\
\hline Evet & $2,5(5)$ & $8,1(16)$ & $10,6(21)$ \\
\hline Hayır & $2,5(5)$ & $43,5(86)$ & $46,0(91)$ \\
\hline Kısmen & $4,6(9)$ & $38,8(77)$ & $43,4(86)$ \\
\hline Toplam & $9,6(19)$ & $90,4(179)$ & $100(198)$ \\
\hline$X 2=6,73 ; \mathbf{p}=\mathbf{0 , 0 3 5}$ & & & \\
\hline
\end{tabular}




\section{Tartışma}

Araştırmada örneklemin çoğunu kadınlar, hemşireler ve meslekte deneyimliler oluşturmakla beraber, yarısından fazlası acil serviste 0-5 yıldır çalışmaktadır. Ülkemizde özellikle genç personelin daha yoğun birimlerde çalıştırıldığı gözlenmektedir. Bazen de acil servis çalışanlarında tükenmeyi önleme amaçlı rotasyon uygulanabilmektedir. Literatürde de acil ünitelerinin riskli ve stresli olmasının etkisi ile personel değişimlerinin sık görüldüğü belirtilmektedir (4). Araştırmamızda çalışanların şiddete maruz kalma durumları incelendiğinde; \%90,4'ü en az bir ya da daha fazla kez sözel/psikolojik şiddete, özellikle de hakarete maruz kalmış olup, sözel şiddet büyük oranda hasta yakını kaynaklıdır. Fiziksel şiddete maruz kalma oranı ise \%23,2 olarak tespit edilmiş olup şiddet davranışının genelde itme ve eşya fırlatma şeklinde gerçekleştiği ve yaklaşık yarısında herhangi bir yaralanma oluşmadığı belirlenmiştir. Fiziksel şiddet davranışının \%45,5 oranında hasta, $\% 41,5$ oranında hasta yakını kaynaklı olup, meslek türü anlamlı bir değişken olarak saptanmamıştır. Literatürde ki benzer çalışma sonuçları incelendiğinde; Ayrancı'nın çalışmasında acil servis çalışanlarında şiddete maruz kalma oranı \%72,3, fiziksel şiddet oranı \%8,5 dir. Daha çok kadınların ve hemşirelerin şiddete maruz kaldığı ve büyük oranda hasta yakını tarafından gerçekleştiği saptanmıştır (18). Kahriman ve Annagür'ün çalışmalarında hasta yakınlarının daha fazla oranda şiddet davranışı gösterdiği belirtilmektedir $(19,20)$. Vural ve ark. tarafından yapılan çalışmada da acil çalışanlarının \%82'sinin şiddete maruz kaldığı, bu oranın \%74'ünün sözel şiddet olduğu ve şiddete maruz kalma ile cinsiyet, yaş ve mesleki kıdem gibi değişkenler arasında anlamlı bir ilişki olmadığı saptanmıştır (1). Türkiye'de yapılan başka bir çalışmada; acil servis çalışanlarının \%85,2'sinin en az bir şiddet türüne maruz kaldığı, bunların \%41,1'i fiziksel saldırı, \%79,6'i sözel taciz, $\% 55,5^{\prime}$ i sözel şiddet ve $\% 15^{\prime} i$ cinsel taciz olarak belirtilmiş, $\% 90,9^{\prime}$ unda şiddet kaynağı hasta yakını olarak ifade edilmiştir (8). Bir derlemede ise hasta ve hasta yakını şiddet uygulama oranları birbirine yakındır (21). Farklı ülkelere ait veriler incelendiğinde; Avustralya'da yapılan bir çalışmada acil servis çalışanlarının son 6 ayda $\% 88,1$ oranında sözel şiddete, $\% 42,6$ oranında fiziksel şiddete maruz kaldığı saptanmıştır. Ayrıca, fiziksel saldırıların genelde tokat atma, yaralama, tekme, ısırma, bedensel akıntılarla ve silahla saldırı, sözel şiddetin ise daha çok tehdit ve taciz şeklinde olduğu belirtilmektedir (22). Filistin'de acil servis çalışanlarının \%76,1'inin son bir yılda şiddete maruz kaldığı, bunların \%35,6'sının fiziksel şiddet olduğu belirlenmiştir (23). Pakistan'da yapılan çalışmada acil servis çaIışanlarında, son bir yılda sözel şiddete maruz kalma oranı
$\% 72,5$, fiziksel şiddete maruz kalma oranı $\% 16,5$ ve vakaIarın daha çok hasta yakını kaynaklı olduğu saptanmıştır (24). Mısır'da acil servis çalışanlarında son bir yılda; şiddete maruz kalma oranı $\% 85,9$, fiziksel şiddet oranı $\% 48,4$, sözel şiddet oranı \%60,2, psikolojik şiddet oranı \%53,9 ve cinsel şiddet oranı \%30,5 olarak belirlenmiştir (25). Yapılan pek çok çalışmada hemşirelerin şiddete daha fazla maruz kaldığı da belirtilmektedir $(1,12,22,23)$. Literatüre göre örneklemimizdeki sözel/psikolojik şiddet oranları nispeten yüksek ve fiziksel şiddet oranları nispeten düşük olarak değerlendirilebilir. Ayrıca çalışmanın yürütüldüğü Muğla ilinde ülkenin önemli turizm ve eğlence merkezleri bulunmakta olup turistlerin ve yazlıkcıların etkisi ile kültürel çeşitlilik ve kültürel geçiş belirgindir. Ayrıca, alkolün satış ve kullanımında ön sıradaki iller arasında yer aldığı Türkiye Tütün Alkol Piyasası Denetleme Kurulu tarafından (2012) raporlanmıştır. Alkol madde kullanımı şiddet olaylarında önemli bir değişken olup $(10,21)$ sözel şiddet oranlarının yüksekliğini değerlendirmede bölgesel özellikler göz önünde bulundurulmalı ve benzer çalışmalarda daha kapsamlı incelenmelidir.

Şiddet travmatik bir olaydır ve olay sonrasında birey; hayal kırıklığı, öfke, depresyon, kendinden utanma, suçluluk, güçsüzlük, özgüvende azalma duyguları yaşamakta; stres ve anksiyetesi artmakta, iş motivasyonu ve performansı olumsuz etkilenmektedir $(3,13,17,21)$ Altıntaş ve Talas ve ark. çalışmalarında şiddet sonrası öne çıkan duygu olarak üzüntü ve öfke saptamıştır $(3,8)$. Çalışmamızda şiddet sonrası çalışanlarda duygu olarak en çok öfke ve işten soğuma/isteksizlik ifade edilmiştir. Sözel/psikolojik şiddete maruz kalanların çoğu psikolojik destek gereksinimi duymadığını, fiziksel şiddete maruz kalanların ise \%37'sinin psikolojik destek gereksinimi olduğu belirlenmiştir. Gereksinim duyanlarda ise ruhsal danışmanlık alan ya da izin kullanan çalışanların oranı oldukça düşüktür. Yurtdışı çalışmalarda psikolojik destek alma oranın oldukça yüksek olduğu görülmektedir (9). Örneklemde ruhsal destek alanların oranının çok düşük olması; iş ortamında ki şiddeti normalleştirme eğilimini veya sağlık çalışanlarının ruhsal hastalıklar ile ilgili önyargılı olabileceğini düşündürmüştür. Ayrıca ülkemizde ruhsal danışmanlık hizmetlerine ulaşma konusunda zorluklar da bulunmaktadır. Çalışanların maruz kaldıkları şiddet olayını raporlama/bildirme durumu; sözel/psikolojik şiddete maruz kalanlarda \%43,5, fiziksel şiddete maruz kalanlarda \%64,5 oranında saptanmış olup, bildirim sonrası çalışanların çoğu tatmin edici bir sonuca ulaşamadığını belirtmiştir. Vural ve ark. tarafından yapılan çalışmada acil servis çalışanlarında şiddeti rapor etme oranı ise $\% 26,8$ olup daha düşük bulunmuştur (1). Filistin'de yapılan bir çalışmada ise şiddeti raporlama oranı \%40 (23), 
Bahar ve ark. tarafından yapılan çalışmada ise $\% 42$ olarak belirtilmiştir (26). Eker ve ark. çalışmasında şiddete maruz kalan sağlık çalışanlarının $\% 90,2$ 'si mevcut yasaların personeli korumadığını, \%88.3'ü ise şiddet olayı sonrası kurumsal destek göremediklerini belirtmiş̧ir (27). Literatürde, genelde şiddeti bildirim oranları düşük olup, raporlama sonrası sağlık çalışanlarının çoğunun sonuç alamadığı, çeşitli nedenler ile bildirim yapmaktan kaçındıkları belirtilmektedir $(4,13,21,26)$. Yakın geçmişte başlatılan Beyaz kod uygulaması telefon ve internet üzerinden yapılan bildirimler ile sürecin kolaylaştırılması ve yaygınlaştırılması için önemli bir adım olsa da adli süreçlerin uzun olması ve cezaların caydırıc bulunmaması bildirimlerin istenilen düzeyde olmamasında etkili sebepler arasında sayılabilir. Kowalenco ve ark. çalışmalarında bir yaralanma olmadıkça şiddet olaylarını raporlamama eğilimi olduğunu, fakat hekimlerin hemşirelerden daha fazla şiddet olaylarını raporladığı ifade edilmektedir (7). Çalışmamızda şiddet olaylarında bildirim oranlarının literatüre göre kısmen daha yüksek oranda olması olumlu bir veri olup, sağlık çaIışanlarının giderek bilinçlendiğini ve beyaz kod kullanımının yaygınlaştığını düşündürmektedir.

Çalışmamızda; şiddet olaylarının en fazla triyaj ya da hasta kabul esnasında ve muayene/müdahale odalarında gerçekleştiği tespit edilmiştir. Literatürde de hasta ile yakın çalışılan, triyaj ve muayene esnasında şiddete maruz kalma oranlarının daha fazla olduğu belirtilmektedir $(5,26)$. Çalışanların çoğu şiddete maruz kalma açısından acil servis ortamını hastanenin diğer birimlerine kıyasla daha riskli olduğunu, şiddet riskinin iş stresini arttırdığını belirtmiştir. Ayrıca, sadece \%5.6'sı çalıştıkları birimdeki güvenlik tedbirlerini yeterli bulmakta olup, şiddete maruz kalan çalışanlarda çalışma koşullarından memnun olmayanların ve çalışmakta olduğu acil ünitesinden ayrılmayı düşünenlerin oranının daha fazla olduğu saptanmıştır $(p<.05)$. Literatürde de iş stresinin, bireyin iyilik halini tehlikeye sokarak kaynakların tüketmesine neden olduğu, iş ortamında stresi arttıran şiddet riski, güvenlik yetersizliği gibi faktörlerin çalışanların hem sağlığını hem de mesleki doyumunu olumsuz etkilediği belirtilmektedir $(17,23,26)$. Benzer çalışmalarda da iş güvenliği tedbirleri yetersiz bulunmaktadır (27). Bu nedenle, çalışanın güvenliğini ve ruhsal sağlığını daha fazla önemseyen, tükenmeyi önleyecek, iş motivasonunu arttıracak girişimlerin gerektiği düşünülmektedir. Illave olarak acil serviste 1-5 yıl arası çalışanlarda fiziksel şiddete maruz kalma oranı daha fazla saptanmıştır $(p<.05)$. Bu veri acil serviste 1-5 yıldır çalışanların oranının fazlalığı ve örneklemin yaklaşık \%30.8'inde mesleki deneyimin 0-5 yıl olması ile ilişkilendirilebilir. Eker ve ark. çalışmasında da 1-4 yıl arası acil serviste çalışanlarda ve 30 yaş altı grupta şiddete maruz kalma oranları daha yüksek olarak saptanmıştır (27). Dolayısı ile şiddete maruz kalmada mesleki deneyim ve personel hareketliliğinin etkili olabileceği, yüksek riskli birimlerde personelin deneyimli olmasına, hizmet içi eğitimlere ve hemşirelerde mezuniyet sonrası eğitim programlarına önem verilmesinin gerektiği söylenebilir.

Şiddeti ve sağlık çalışanlarına yönelik şiddet olaylarını ve nedenlerini anlama çabaları devam etmektedir. Ülkemizde yapılan bazı çalışmalarda sağlıkta şiddetin nedenleri; şiddetin cezasız kalması, uygulanan sağlık politikaları, hasta ve yakınlarının ihmal edildiklerini düşünmeleri, medyadaki yanlış haberler, hasta ve yakınlarının bilgi eksikliği ve güven yetersizliği, alkol kullanımı ve güvenlik tedbirlerinde yetersizlikler olarak belirtilmektedir $(4,20)$. Tüm dünyada şiddetin sağlık çalışanları için önemini koruyan bir sorun olması nedeniyle pek çok organizasyon tarafından önlemenin önemi vurgulanmakta ve önleme programları yürütülmektedir $(7,15,16)$. Literatürde; risk değerlendirme, agresyon ve şiddeti önlemeye yönelik eğitim, kendini savunma, iletişim ve baş etme becerilerinin güçlendirilmesi, güvenlik tedbirlerinin arttıııması, fiziksel düzenlemelerin yapılması, etkin önleme politikalarının ve programların oluşturulması, çalışanların desteklenmesi öneriler arasındadır $(15,16,25,27)$. Ülkemizde bu yönde atılan adımlar nispeten yenidir. Bu konuda daha etkin ve planlı programlara, kararlı politikalara, katıımcı ve çalışan merkezli yaklaşımlara gereksinim bulunmaktadır. İlave olarak; şiddet davranışında bulunanlar için cezaların caydırıcılığının sağlanması, mesleki örgütlenmenin desteklenmesi de yararlı olacaktır.

\section{Sonuç ve öneriler}

Sonuç olarak; örneklemde sözel şiddet oranları literatüre göre nispeten yüksek, fiziksel şiddet oranları düşük bulunmuştur. Acil servislerde karşılaşılan şiddet davranışları daha çok hasta yakını kaynaklı olup şiddet olaylarının bildirim oranları yüksektir. İş ortamı güvenlik tedbirleri çalışanlarca yeterli görülmemiş ve şiddet; çalışanların çaIışma ortamına ilişkin memnuniyetini azaltan etkenlerden biri olarak değerlendirilmiştir. Şiddet maruziyetinin ruhsal duruma etkisi ve ruhsal desteğin önemi konusunda çalışanların ve yöneticilerin farkındalığı da arttırıımalıdır. Her ne kadar şiddeti ortadan kaldırmak mümkün olmasa da şiddeti azaltmak için ülkemizde daha organize, etkin önleme programlarına gereksinim duyulmaktadır.

\section{Açıklamalar}

Bu çalışmada zaman ayırıp gönüllü katılım gösteren acil servis çalışanlarına teşekkür ederiz. 


\section{Kaynaklar}

1. Vural F, Çiftçi S, Fil Ş, Dura A, Vural B. Bir devlet hastanesinde acil servis çalışanlarına yönelik şiddet: Şiddetin rapor edilme sıklığı. Türk Aile Hek Derg 2013;17:147-52. [CrossRef]

2. Illhan MN, M Çakır, Tunca MZ, E Avcı, E Çetin, Önder Aydemir. Toplum gözüyle sağlık çalışanlarına şiddet: Nedenler, tutumlar, davranışlar. Gazi Med J 2013;24:5-10. [CrossRef]

3. Altıntaş N. Sağlık kurumlarında çalışan hemşirelere yönelik şiddetin belirlenmesi. İstanbul Üniversitesi, Sağlık Bilimleri Enstitüsü, Psikiyatri Hemşireliği AD, Yüksek Lisans Tezi, 2006, İstanbul. Erişim: http://www.saglikcalisanisagligi.org/tezler/192944.pdf

4. Demiroğlu T, Kılınç E, Atay E. Sağlık çalışanlarına uygulanan şiddet: Kilis ili örneği. Sağlık Bil Derg 2015;24:49-55.

5. ALBashtawy M, Aljezawi M. Emergency nurses' perspective of workplace violence in Jordanian hospitals: A national survey. Int Emerg Nurs 2016;24:61-5. [CrossRef]

6. Llor-Esteban B, Sánchez-Munoz M, Ruiz-Hernándeza JA, JiménezBarbero JA. User violence towards nursing professionals in mental health services and emergency units. Eur J Psychol Appl Legal Context 2017;9:33-40. [CrossRef]

7. Kowalenco T, Cunningham R, Sachs CJ, Gore R, Barata IA, Gates D, et al. Workplace violence in emergency medicine: Current knowledge and future directions. J Emerg Med 2012;43:523-31. [CrossRef]

8. Talas MS, Kocaöz S, Akgüç S. A survey of violence against staff working in the emergency department in Ankara, Turkey. Asian Nurs Res 2011;5:197-203. [CrossRef]

9. Mantzouranis G, Fafliora E, Bampalis VG, Christopoulou I. Assessment and analyis of workplace violence in a greek tertiary hospital. Arch Environ Occup Health 2015;70:256-64. [CrossRef]

10. Camcı OK, Kutlu Y. Kocaeli'de sağlık çalışanlarına yönelik işyeri şiddetinin belirlenmesi. Psikiyatri Hem Derg 2011;2:9-16. Erişim: http://www.journalagent.com/phd/pdfs/PHD_2_1_9_16.pdf

11. Kowalenko T, Gates D, Gillespie GL, Succop P. Mentzel TK. Prospective study of violence against ED workers. Am J Emerg Med 2013;31:197205. [CrossRef]

12. Gillespie GL, Pekar B, Byczkowski TL, Fisher BS. Worker, workplace, and community/environmental risk factors for workplace violencein emergency departments. Arch Environ Occup Health 2017;72:7986. [CrossRef]

13. Keser Özcan N, Bilgin H. Türkiye'de sağlık çalışanlarına yönelik şiddet: Sistematik derleme. Türkiye Klinikleri J Med Sci 2011;6:1442-56. [CrossRef]

14. Aydin B, Kartal M, Midik O, Buyukakkus A. Violence against general practitioners in Turkey. J Interpers Violence 2010;24:1980-95. [CrossRef]
15. Gates D, Gillespie G, Smith C, Rode J, Kowalenko T, Smith B. Using action research to plan a violence prevention program for emergency departments. J Emerg Nurs 2011;37:32-9. [CrossRef]

16. Lin LY, Juan CW, Chu C. The needs and potential solutions for improvement of workplace violence management in emergency departments in Taiwanese hospitals. J Acute Med 2014;4:13-9. [CrossRef]

17. De Puy J, Romain-Glassey N, Gut M, Pascal W, Mangin P, Danuser B. Clinically assessed consequences of workplace physical violence. Int Arch Occup Environ Health 2015;88:213-24. [CrossRef]

18. Ayrancı Ü. Violence toward health care workers in emergency departments in west Turkey. J Emerg Med 2005;28:361-5. [CrossRef]

19. Annagür B. Sağlık çalışanlarına yönelik şiddet risk faktörleri, etkileri, değerlendirilmesi ve önlenmesi. Psikiyatride Güncel Yaklaşımlar 2010;2:161-73. Erişim: http://www.cappsy.org/archives/vol2/no2/ cap_02_09.pdf

20. Kahriman İ. Hemşirelerin sözel ve fiziksel şiddete maruz kalma durumlarının belirlenmesi. Psikiyatri Hem Derg 2014;5:77-83. [CrossRef]

21. Kahya B, Çetin C, Cebeci F. Acil servis hemşirelerine yönelik şiddet: sistematik derleme. Firat Tıp Derg 2016;21:170-6.

22. Partridge B, Affleck J. Verbal abuse and physical assault in the emergency department: Rates of violence, perceptions of safety, and attitudes towards security. Australas Emerg Nurs J 2017;20:13945. [CrossRef]

23. Hamdan M, Abu Hamra A. Workplace violence towards workers in the emergency departments of Palestinian hospitals: A crosssectional study. Hum Resour Health 2015;13:2-9. [CrossRef]

24. Zafar W, Siddiqui E, Shehzad MU, Khan UR, Jamali S, Razzak J. Health care personnel and workplace violence in the emergency departments of a volatile metropolis: Results from Karachi, Pakistan. J Emerg Med 2013;45:761-72. [CrossRef]

25. Abou-ElWafa HS, El-Gilany AH, Abd-El-Raouf SA, Abd-Elmouty SM, El-Sayed R, El-Sayed H. Workplace Violence Against Emergency Versus Non-Emergency Nurses in Mansoura University Hospitals, Egypt. J Interpers Violence 2015;30:857-72. [CrossRef]

26. Bahar A, Şahin S, Akkaya Z, Alkayiş M. Acil serviste çalışan hemşirelerin şiddete maruz kalma durumu ve iş doyumuna etkili olan faktörlerin incelenmesi. Psikiyatri Hem Derg 2015;6:57-64. [CrossRef]

27. Eker HH, Özder A, Tokaç M, Topçu I, Tabu A. Aggression and violence towards health care providers, and effects there of. Arch Psychiatr Psychother 2012;4:19-29. Erişim: http://www.archivespp.pl/ uploads/images/2012_14_4/19Eker_ArchivesPP_4_2012.pdf 